\title{
PELATIHAN AKUNTANSI DAN PENYUSUNAN LAPORAN KEUANGAN USAHA KECIL BAGI SISWA SEKOLAH MENENGAH KEJURUAN (SMK) PGRI DI SURAKARTA
}

\author{
Lilis Sulistyani $^{1^{*}}$, Ifah Lathifah ${ }^{2}$ dan Shandy Marsono ${ }^{3}$ \\ ${ }^{1,3}$ Dosen S1 Akuntansi STIE - AUB-Surakarta \\ ${ }^{2}$ Dosen Magister Manajemen STIE-AUB-Surakarta \\ *Email: lilissulistyani44@yahoo.co.id
}

\begin{abstract}
Abstrak
Pengabdian ini bertujuan untuk memberikan pelatihan akuntansi dan penyusunan laporan keuangan Usaha Mikro Kecil Bagi Siswa Sekolah Menengah Kejuruan (SMK) PGRI Di Surakarta.

Kegiatan pelatihan akuntansi dan penyusunan laporan keuangan Usaha kecil bagi siswa SMK ini dilakukan dengan cara presentasi, diskusi dan simulasi. Sasaran dari kegiatan Pengabdian Kepada Masyarakat ini adalah Siswa Sekolah Menengah Kejuruan (SMK) PGRI di Surakarta. Siswa SMK PGRI setelah menerima materi bidang kewirausahaan, dipandang perlu untuk memperoleh pelatihan mengenai akuntansi dan penyusunan laporan keuangan usaha kecil. Solusi yang ditawarkan oleh tim pengabdian kepada masyarakat STIE-AUBSurakarta yaitu Tim PKM STIE-AUB-Surakarta mengadakan pelatihan akuntansi dan penyusunan laporan keuangan Usaha Kecil Bagi Siswa Sekolah Menengah Kejuruan (SMK) PGRI Di Surakarta

Tindak lanjut dari kegiatan ini yaitu akan dilakukan binaan dan pendampingan berkelanjutan, sehingga peserta pendampingan khususnya Siswa Sekolah Menengah Kejuruan (SMK) PGRI di Surakarta, dapat menjalankan praktik akuntansi sederhana sampai dengan penyusunan laporan keuangan untuk usaha kecil sesuai dengan Standar Akuntansi Keuangan Entitas Mikro, Kecil, dan Menengah (SAK EMKM). Harapan lebih jauh ke depan, Siswa Sekolah Menengah Kejuruan (SMK) PGRI di Surakarta ini akan memiliki motivasi yang lebih kuat untuk dapat berwirausaha secara akuntabel. Alasan yang mendasari adalah siswa SMK PGRI Surakarta telah memiliki bekal yang memadai tentang cara mendirikan usaha kecil sekaligus bagaimana menyusun laporan keuangan bagi usaha kecil.
\end{abstract}

Kata Kunci: Akuntansi, Laporan Keuangan, Usaha Kecil, Sekolah Menengah Kejuruan.

\section{SUMMARY}

This service aims to provide accounting training and preparation of financial statements for Micro Small Businesses for Vocational High School (SMK) Students in Surakarta.

Accounting training activities and preparation of financial statements for small businesses for vocational students are carried out by means of presentations, discussions and simulations. The target of this Community Service activity is PGRI Vocational High School (SMK) Students in Surakarta. Students of SMK PGRI after receiving material in the field of entrepreneurship, are deemed necessary to obtain training in accounting and preparation of financial statements for small businesses. The solution offered by the community service team of STIE-AUB-Surakarta is the STIE-AUB-Surakarta PKM Team conducts accounting training and preparation of Small Business Financial Reports for PGRI Vocational High School Students in Surakarta

The follow up of this activity will be carried out fostered and ongoing assistance, so that the participants of the assistance, especially the Vocational High School Students (SMK) in Surakarta, can carry out simple accounting practices up to the preparation of financial reports for small businesses according to the Financial Accounting Standards of Micro, Small Entities, and Middle School (SAK EMKM). Further expectations in the future, PGRI Vocational High School (SMK) students in Surakarta will have stronger motivation to be able to account for entrepreneurship accountably. The underlying reason is that the Surakarta PGRI Vocational School students have adequate provisions on how to set up a small business as well as how to prepare financial reports for small businesses.

Keywords: Accounting, Financial Statements, Small Business,Vocational High Schools. 
A. Pendahuluan

Masyarakat di Indonesia diberikan kemudahan untuk mendirikan sebuah bisnis ditunjukkan dengan adanya kemudahan usaha mikro, kecil, dan menengah yang kemudian disebut dengan UMKM memperoleh izin ketika akan melaksanakan kegiatan bisnis. Data dari Kementerian Koperasi dan UMKM tahun 2017, pangsa unit usaha UMKM sekitar 99,99\% atau 62.922.617 unit, jika dibandingkan dengan usaha besar hanya pada kisaran pangsa $0,01 \%$ atau 5.460 unit. Hal ini menandakan bahwa UMKM dinilai memiliki ketahanan terhadap krisis ekonomi dan memiliki potensi untuk berkembang di Indonesia.

Undang-Undang Nomor 20 Tahun 2008 tentang Usaha Mikro, Kecil dan Menengah (UMKM) menyatakan bahwa usaha kecil adalah usaha ekonomi produktif yang berdiri sendiri, yang dilakukan oleh orang perorangan atau badan usaha yang bukan merupakan anak perusahaan atau bukan cabang perusahaan yang dimiliki, dikuasai atau menjadi bagian baik langsung maupun tidak langsung dari usaha menengah atau usaha besar yang memenuhi kriteria usaha kecil sebagaimana dimaksud dalam undang-undang ini.

Usaha kecil ini meliputi usaha kecil informal dan usaha kecil tradisional. Adapun usaha kecil informal adalah berbagai usaha yang belum terdaftar, belum tercatat, dan belum berbadan hukum, antara lain petani penggarap, industri rumah tangga, pedagang asongan, pedagang keliling, pedagang kaki lima, dan pemulung. Adapun usaha kecil tradisional adalah usaha yang menggunakan alat produksi sederhana yang digunakan secara turun menurun, dan atau berkaitan dengan seni dan budaya (Anoraga, 2000).

Keberhasilan usaha kecil dalam menjalankan bisnis tidak terlepas dari kemampuan mengelola keuangan. Ketidakmampuan mengelola keuangan akan berimbas bagi kelangsungan hidup usaha kecil. Sebagaimana Warsono dkk (2010:8) menyatakan bahwa pengelolaan dana yang buruk akan mengakibatkan ketidakmampuan perusahaan untuk mencegah, mendeteksi ataupun mengkoreksi tindak kecurangan yang terjadi. Pelaku usaha kecil seringkali mencampuradukkan antara uang hasil usaha dengan uang milik pribadi. Hal ini dapat berakibat pada saat tertentu, usaha kecil akan kehabisan uang untuk operasional.

Permasalahan lain yang juga sering dihadapi usaha kecil untuk dapat berkembang adalah pemahaman tentang informasi akuntansi (Wirjono dan Raharjono 2012). Sebagian besar usaha kecil tidak melakukan pencatatan dengan baik atas transaksi yang terjadi, apalagi menyusun laporan keuangan. Kondisi ini tentu akan menghambat usaha kecil untuk berkembang, karena tidak diketahui maju mundurnya usaha yang telah dijalankan. Apabila usaha kecil akan meningkatkan kapasitas modal dengan mengajukan kredit ke lembaga formal seperti perbankan, tentu akan mengalami hambatan karena usaha kecil tidak memiliki laporan keuangan. Perbankan sebagai lembaga kredit telah menyediakan fasilitas kredit lunak bagi usaha kecil. Namun ada persyaratan yang harus dipenuhi yaitu pengajuan kredit lunak harus disertai laporan keuangan sebagai dasar kelayakan pemberian kredit oleh perbankan. Akuntansi dan laporan keuangan dengan demikian memiliki peran penting bagi keberlangsungan usaha kecil di Indonesia.

Akuntansi menurut Mulyadi (2010) merupakan suatu sistem yang mengelola masukan berupa data operasi dan data keuangan untuk menghasilkan keluaran berupa informasi keuangan yang dibutuhkan para pemakai informasi tersebut. Undang -Undang Usaha kecil No. 9 tahun 1995 secara tersirat mewajibkan usaha kecil untuk melakukan pencatatan yang baik. Pemerintah dengan demikian telah menegaskan pentingnya pencatatan dan penyelenggaraan informasi akuntansi bagi usaha kecil, walaupun dalam kenyataannya desakan hukum (law enforcement) dari pihak regulator belum memadai (Pinasti, 2007). Jika usaha kecil menjalankan praktik akuntansi, dengan sendirinya akan dapat menghasilkan laporan keuangan. Namun pelaksanaan pembukuan atau akuntansi bagi usaha kecil bukan merupakan hal yang mudah. Kesulitan ini diakibatkan keterbatasan yang dialami oleh usaha kecil, yaitu kurangnya pemahaman mengenai akuntansi, rumitnya proses akuntansi dan adanya anggapan bahwa laporan keuangan tidak penting bagi usaha kecil. 
Berdasarkan masalah kerumitan dan kurangnya pengetahuan pelaku usaha terkait laporan akuntansi, maka Dewan Standar Akuntansi Keuangan (DSAK) yang bernaung dalam Ikatan Akuntan Indonesia (IAI) telah menyusun suatu standar yang disesuaikan untuk membantu pelaku UMKM dalam menyediakan laporan keuangan perusahaan. Standar ini disebut dengan Standar Akuntansi Keuangan Entitas Mikro, Kecil, dan Menengah (SAK EMKM), yang mulai efektif diterapkan pada 1 Januari 2018.

SAK EMKM merupakan standar yang telah disusun untuk menyesuaikan kebutuhan pelaporan keuangan bagi UMKM, sehingga komponen laporan keuangan yang disajikan atau diwajibkan untuk dilaporkan lebih sedikit dibandingkan standar akuntansi lainnya. Komponen laporan keuangan berdasarkan SAK EMKM terdiri dari Laporan posisi keuangan, Laporan laba rugi dan catatan atas laporan keuangan.

Laporan posisi keuangan yaitu laporan yang menyajikan informasi terkait jumlah aset (harta), liabilitas (kewajiban), dan ekuitas (modal) per tanggal laporan. Laporan laba rugi yang merupakan laporan keuangan yang menggambarkan informasi terkait kinerja keuangan entitas dalam suatu periode. Unsur yang terkandung dalam laporan laba rugi adalah penghasilan (income) dan beban (expenses), perusahaan dinilai memiliki kinerja yang baik jika penghasilan yang diperoleh lebih besar dari pada beban yang dikeluarkan. Kemudian catatan atas laporan keuangan merupakan laporan yang menjelaskan secara rinci terkait jumlah nominal yang muncul dalam laporan keuangan lainnya ditambah dengan beberapa hal yang diwajibkan untuk diungkapkan. Berdasarkan komponen tersebut dapat diketahui bahwa laporan keuangan yang disyaratkan bagi usaha mikro, kecil, dan menengah lebih sedikit dan mudah, apabila dibandingkan dengan laporan keuangan yang disyaratkan bagi usaha besar dengan SAK berbasis IFRS dan perusahaan besar yang menggunakan SAK-ETAP.

Siswa Sekolah Menengah Kejuruan (SMK) khususnya siswa sekolah menengah kejuruan (SMK) PGRI di Surakarta adalah siswa advokasi yang dipersiapkan untuk menjadi pribadi yang mandiri secara ekonomi. Para siswa SMK setelah lulus, diharapkan akan dapat berwirausaha sesuai dengan keahlian yang telah diperoleh selama proses studi. Berwirausaha tentu tidak dapat dilepaskan dari bagaimana menjaga keberlangsungan dari usaha yang telah dirintis. Salah satu upaya yang dapat dilakukan oleh wirausahawan adalah menjalankan praktik akuntansi secara baik. Tujuannya agar memiliki informasi akuntansi untuk memantau maju mundurnya usaha yang dijalankan.

Para siswa sekolah menengah kejuruan (SMK) PGRI di Surakarta yang mengambil jurusan otomotif dan listrik, telah dipersiapkan oleh pihak sekolah untuk dapat mandiri. Artinya jika siswa telah lulus akan dapat berwirausaha sesuai dengan keahliannya seperti mendirikan bengkel atau membuka toko sparepart motor/mobil ataupun juga usaha yang lain yang diminati. Namun sebagai calon wirausahawan, bekal siswa untuk dapat mengelola usaha dengan baik belum cukup. Alasan yang mendasari bahwa siswa SMK PGRI Surakarta jurusan listrik dan otomotif, tidak mendapatkan materi ajar mengenai ilmu akuntansi. Hal ini sangat wajar karena kurikulum yang disiapkan bagi siswa SMK jurusan listrik dan otomotif, lebih didominasi ilmu kelistrikan dan otomotif dan tidak bersentuhan sama sekali dengan ilmu akuntansi.

Tim pengabdian kepada masyarakat Sekolah Tinggi Ilmu Ekonomi -AUB- Surakarta, khususnya jurusan Akuntansi berdasarkan fenomena di lapangan merasa sangat terpanggil untuk memberikan sumbangan pemikiran bagi SMK PGRI di Surakarta sebagai bentuk kepedulian terhadap perkembangan usaha kecil di lingkungan Kota Surakarta. Kepedulian ini diwujudkan dalam langkah nyata yaitu akan dilakukannya pelatihan dan pendampingan tentang akuntansi dan penyusunan laporan keuangan usaha kecil yang sesuai dengan standar akuntansi keuangan (SAK) bagi usaha kecil yaitu SAK EMKM. Harapan dari kegiatan ini yaitu akan dapat meningkatkan kemampuan dan keahlian bagi para siswa SMK PGRI di Surakarta dalam bidang akuntansi. Para siswa SMK PGRI di Surakarta, setelah lulus nanti akan lebih percaya diri untuk berwirausaha. Yaitu dengan membuka usaha kecil yang akan dikelola dengan proses pencatatan/akuntansi yang baik berdasarkan pada SAK EMKM. 
B. Perumusan Masalah

Pertumbuhan jumlah usaha kecil yang signifikan di kota Surakarta, nampaknya belum didukung oleh kemampuan sumber daya manusia yang memadai khususnya pada bidang akuntansi. Kondisi ini jelas menimbulkan keprihatinan dan permasalahan pada usaha kecil tersebut. Para siswa sekolah menengah kejuruan (SMK) adalah calon-calon usahawan di masa depan. Namun siswa SMK, khususnya siswa SMK PGRI Surakarta tidak mendapatkan bekal yang cukup untuk mampu menjalankan usaha mandiri yaitu terkait proses pencatatan atau akuntansi. Padahal aktivitas akuntansi akan bermuara pada informasi akuntansi yang sangat penting bagi keberlangsungan usaha/bisnis. Berdasarkan pada fenomena ini, maka Tim pengabdian kepada masyarakat Sekolah Tinggi Ilmu Ekonomi -AUB- Surakarta, mengambil langkah inisiatif dan antisipasi untuk membekali para siswa SMK PGRI di Surakarta sebagai calon-calon usahawan di masa depan. Adapun permasalahan yang dirumuskan yaitu bagaimana meningkatkan pemahaman dan kemampuan ilmu akuntansi bagi para siswa Sekolah Menengah Kejuruan (SMK) PGRI di Surakarta untuk mempersiapkan diri sebagai usahawan muda setelah lulus dari sekolah ?"'

C. Tujuan Kegiatan

Tujuan dari kegiatan ini adalah Tim pengabdian pada masyarakat memberikan pelatihan secara komprehansif kepada para siswa SMK PGRI di Surakarta tentang proses penyusunan laporan keuangan bagi usaha kecil sesuai dengan Standar Akuntansi Keuangan Entitas Mikro, Kecil, dan Menengah (SAK EMKM). Tujuan lanjutan adalah memberikan pembinaan kepada para siswa SMK PGRI di Surakarta tentang penyusunan laporan keuangan bagi usaha kecil sesuai dengan Standar Akuntansi Keuangan Entitas Mikro, Kecil, dan Menengah (SAK EMKM).

D. Pemecahan Masalah

Tim Pengabdian Kepada Masyarakat STIE -AUB- Surakarta setelah mengadakan pendekatan dan melakukan pengamatan ternyata bahwa siswa SMK PGRI di Surakarta khususnya jurusan listrik dan otomotif tidak menerima materi pembelajaran ilmu akuntansi. Jika para siswa SMK tidak mendapatkan materi ajar ilmu akuntansi, tentu bekal untuk menjadi wirausahawan menjadi kurang lengkap.

Solusi yang ditawarkan oleh tim pengabdian kepada masyarakat STIE-AUB-Surakarta untuk mengatasi permasalahan yang dihadapi oleh pihak sekolah khususnya para siswa SMK PGRI di Surakarta yaitu Tim PKM akan mengadakan pelatihan akuntansi dan penyusunan laporan keuangan bagi usaha kecil yang sesuai dengan Standar Akuntansi Keuangan Entitas Mikro, Kecil, dan Menengah (SAK EMKM).

E. Bentuk Kegiatan

Kegiatan ini akan dilaksanakan dalam bentuk:

1. Penyuluhan, yaitu memberikan materi kepada para siswa SMK PGRI di Surakarta untuk dapat memahami dan dapat melakukan siklus akuntansi secara baik dan benar sesuai dengan Standar Akuntansi Keuangan Entitas Mikro, Kecil, dan Menengah (SAK EMKM).

2. Pembinaan, yaitu membina para siswa SMK PGRI di Surakarta dalam proses penyusunan laporan keuangan melalui siklus akuntansi yang benar sesuai dengan Standar Akuntansi Keuangan Entitas Mikro, Kecil, dan Menengah (SAK EMKM).

F. Hasil Dan Pembahasan

Kegiatan Pengabdian Kepada Masyarakat (PKM) STIE - AUB - Surakarta yang diselenggarakan dengan khalayak sasaran siswa Sekolah Menengah Kejuruan (SMK) PGRI 
Surakarta telah berjalan dengan baik dan lancar. Para siswa dan juga guru di SMK PGRI Surakarta sangat antusias mengikuti kegiatan PKM ini. Beberapa siswa secara terbuka menyampaikan keinganan mereka untuk secara lebih intensif menerima bimbingan atau pendampingan, agar benar-benar mampu melakukan siklus akuntansi bagi usaha mikro kecil menengah sesuai dengan Standar Akuntansi Keuangan Entitas Mikro, Kecil, dan Menengah (SAK EMKM).

Adapun hasil kegiatan pengabdian kepada masyarakat ini adalah para siswa dan juga guru di SMK PGRI Surakarta menjadi lebih paham mengenai pentingnya akuntansi dan laporan keuangan bagi usaha mikro kecil menengah (UMKM). Laporan keuangan merupakan alat yang dapat digunakan oleh sebuah unit usaha untuk mengetahui perkembangan usaha teresbut. Hasil yang lebih nyata dari pelaksanaan pengabdian ini, akan dilakukan tahapan pengecekan di lapangan untuk menentukan tindakan atau kegiatan pengabdian selanjutnya berupa pendampingan penyusunan laporan keuangan. Artinya keberhasilan dari kegiatan ini dapat dilihat dari antusiasme para siswa di SMK PGRI Surakarta untuk dapat menyusun laporan keuangan bagi usaha mikro kecil menengah. Semangat atau kemauan dan kemampuan para siswa dalam menyusun laporan keuangan ini menunjukkan bahwa binaan yang dilakukan oleh tim pengabdian pada masyarakat STIE-AUB-Surakarta relatif berhasil. Harapan jauh ke depan bahwa siswa SMK PGRI Surakarta setelah lulus, benar-benar akan berwirausaha dengan sehat. Artinya setelah lulus para siswa dapat menjalankan usaha dengan baik dan benar meski berskala kecil atau mikro, yaitu dari usaha yang dijalankan akan disusun laporan keuangan sesuai dengan Standar Akuntansi Keuangan Entitas Mikro, Kecil, dan Menengah (SAK EMKM).

G. Kesimpulan Dan saran

Pelaksanaan kegiatan Pengabdian Kepada Masyarakat (PKM) STIE - AUB - Surakarta yang telah diselenggarakan dengan khlayak sasaran siswa Sekolah Menengah Kejuruan (SMK) PGRI Surakarta, menghasilkan kesimpulan :

1. Para siswa Sekolah Menengah Kejuruan (SMK) PGRI Surakarta, sebagai peserta kegiatan pelatihan sangat antusias atau termotivasi untuk dapat menjalankan siklus akuntansi bagi usaha kecil - mikro sesuai dengan Standar Akuntansi Keuangan Entitas Mikro, Kecil, dan Menengah (SAK EMKM).

2. Guru pendamping siswa kegiatan pelatihan juga sangat antusias dengan kegiatan ini dan berharap secara bertahap terus tumbuh kemauan siswa untuk mendirikan usaha kecil -mikro yang akuntabel.

3. Kegiatan pelatihan ini telah membuka wawasan para siswa SMK dalam proses pengembangan jiwa membangun usaha kecil mikro yang berbasis akuntansi.

4. Tindak lanjut dari kegiatan ini perlu dilakukan baik berupa binaan dan pendampingan berkelanjutan, sehingga peserta pendampingan khususnya siswa SMK PGRI di Surakarta dapat menjalankan praktik berwirausaha yang akuntabel. Harapan lebih jauh ke depan, dari kegiatan tindaklanjut ini adalah siswa lulusan dari SMK ini akan mampu berwirausaha dan menerapkan akuntansi bagi usaha kecil - mikro sesuai dengan Standar Akuntansi Keuangan Entitas Mikro, Kecil, dan Menengah (SAK EMKM).

Beberapa saran yang dapat disampaikan oleh Tim Pengabdian Kepada Masyarakat (PKM) setelah pelaksanaan kegiatan ini, yaitu pihak Sekolah Menengah Kejuruan (SMK) PGRI Surakarta, perlu terus mendorong kemauan para siswa untuk mau dan mampu membangun usaha kecil mikro yang akuntabel. Sekolah Menengah Kejuruan (SMK) PGRI Surakarta, secara periodik/berkala dapat mengundang entrepreneur - entrepreneur muda sebagai pembicara untuk lebih memotivasi para siswa dalam mengembangkan jiwa berwirausaha yang akuntabel.

\section{UCAPAN TERIMAKASIH}


Dalam kesempatan ini pula, kami Tim Pengabdian Kepada Masyarakat STIE - AUB Surakarta mengucapkan terimakasih, yang pertama kepada pimpinan Sekolah Tinggi Ilmu Ekonomi Adi Unggul Bhirawa Surakarta khususnya Lembaga Penelitian dan Pengabdian Pada Masyarakat yang telah memberikan ijin dan menyediakan sarana dan prasarana kegiatan ini. Kedua, bagi para siswa dan guru di Sekolah Menengah Kejuruan (SMK) Persatuan Guru Republik Indonesia (PGRI) Surakarta atas partisipasi dan kerjasama yang telah diberikan, sehingga kegiatan pengabdian masyarakat dapat terlaksana dengan baik dan lancar sesuai dengan yang direncanakan.

Kami menyadari bahwa kegiatan pengabdian kepada masyarakat ini tidak luput dari kekurangan, sehingga segala kritik dan saran yang membangun senantiasa kami harapkan dan akan kami terima dengan senang hati. Akhir kata kami sangat berharap, semoga hasil dari kegiatan pengabdian kepada masyarakat ini dapat bermanfaat dan akan disusul dengan kegiatan berikutnya yang berkesinambungan.

\section{REFERENSI}

Haryono Yusuf, Dasar-Dasar Akuntansi, STIE YKPN Yogyakarta, 2014.

Ikatan Akuntan Indonesia, Standard Akuntansi Keuangan, Salemba Empat, Jakarta, 2007

Mulyadi, Sistem Akuntansi, Salemba Empat, Jakarta, 2003

Soemarso, Akuntansi Suatu Pengantar. Salemba Empat, Jakarta, 2012

Suwarjono, Teori Akuntansi, BPFE, Yogyakarta, 2004.

Zaki Baridwan, Intermediate Accounting, BPFE, Yogyakarta 